\title{
Luca Colliva. "Note su alcuni astragali di period achemenide - post-achemenide rinvenuti a Persepolis West"
}

\section{Rémy Boucharlat}

\section{(2) OpenEdition}

Journals

Édition électronique

URL : https://journals.openedition.org/abstractairanica/53561

DOI : 10.4000/abstractairanica.53561

ISSN : 1961-960X

Éditeur :

CNRS (UMR 7528 Mondes iraniens et indiens), Éditions de l'IFRI

Référence électronique

Rémy Boucharlat, « Luca Colliva. "Note su alcuni astragali di period achemenide - post-achemenide rinvenuti a Persepolis West" », Abstracta Iranica [En ligne], Volume 42-43 | 2021, document 69, mis en ligne le 30 décembre 2021, consulté le 18 décembre 2022. URL : http://journals.openedition.org/ abstractairanica/53561 ; DOI : https://doi.org/10.4000/abstractairanica.53561

Ce document a été généré automatiquement le 18 décembre 2022.

Tous droits réservés 


\title{
Luca Colliva. "Note su alcuni astragali di period achemenide - post-achemenide rinvenuti a Persepolis West"
}

\author{
Rémy Boucharlat
}

\section{RÉFÉRENCE}

Luca Colliva. "Note su alcuni astragali di period achemenide - post-achemenide rinvenuti a Persepolis West", Quaderni di Vicino Oriente XV, 2019, 75-88.

1 Le volume de la revue est consacré aux artefacts en ivoire en os au Proche-et Moyen Orient dans l'Antiquité et le Moyen-Âge. L'A. offre une contribution sur une demidouzaine d'astragales de caprinés trouvées dans deux tranchées proches l'une de l'autre lors des fouilles irano-italiennes de Persepolis West, au pied e la terrasse. Il s'interroge sur leur fonction sur ce site. Parmi ces objets, le plus souvent considérés comme des pièces de jeu, ou des amulettes lorsqu'ils sont percés, ou encore des éléments symboliques, certains portent des traces de polissage sur certaines faces, de sorte qu'une fonction d'outils est envisagée, par exemple pour tanner le cuir, activité que suggèreraient d'autres éléments de la fouille. Tout ce secteur est considéré, depuis les prospections de surface puis les fouilles, comme un secteur d'activités artisanales pour Persépolis. Les dates que suggèrent les positions stratigraphiques diverses des astragales incluent la période achéménide, mais aussi les siècles suivants. 


\section{AUTEURS}

\section{RÉMY BOUCHARLAT}

UMR 5133 CNRS-Université de Lyon 